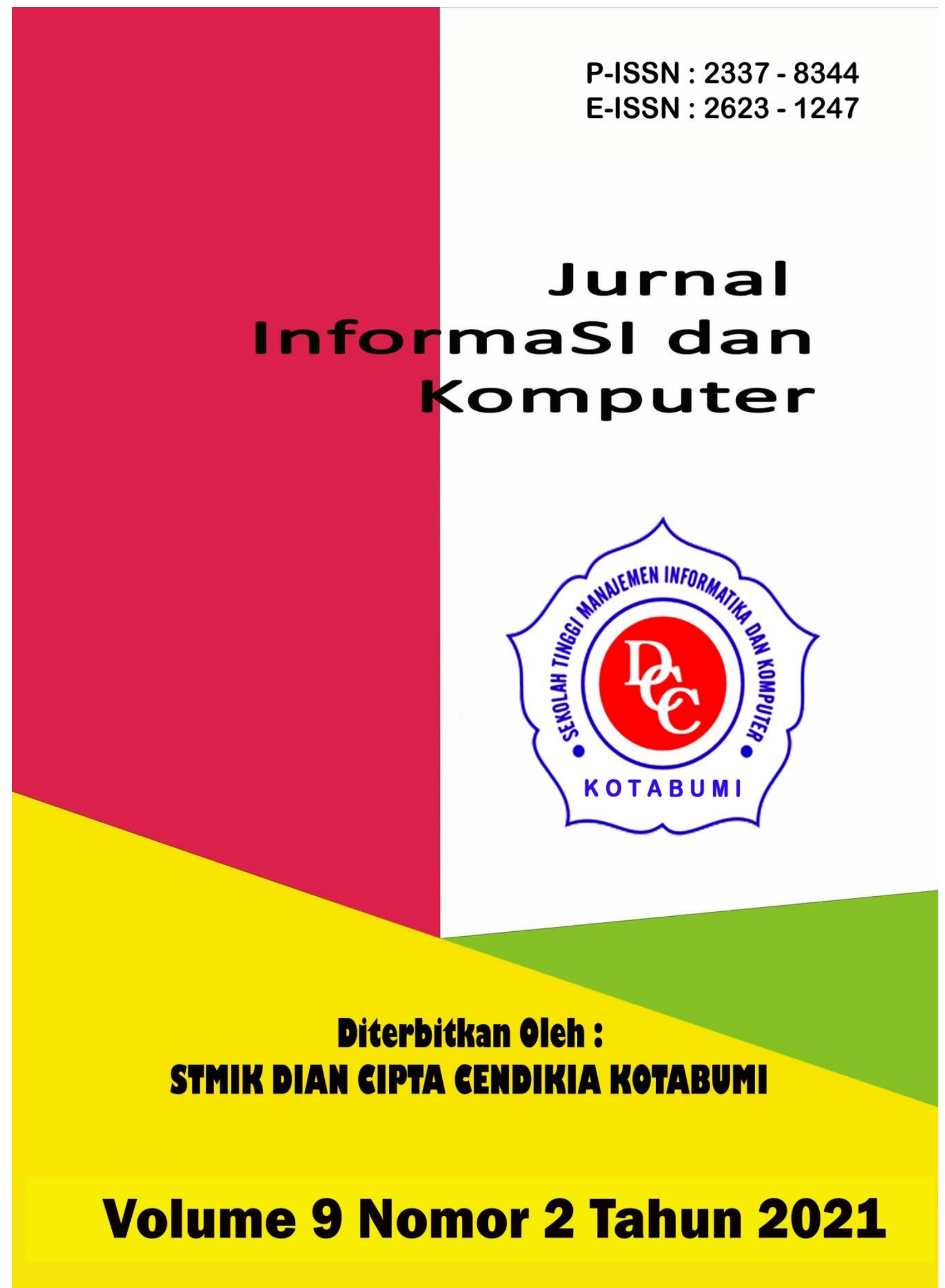


Penerbit Lembaga Penelitian STMIK Dian Cipta Cendikia Kotabumi

Hak atas naskahh/tulisan tetap berada pada penulis, isi diluar tangung jawab penerbit dan Dewan Penyunting 


\section{PENGANTAR REDAKSI}

Puji syukur dipanjatkan kehadirat Tuhan Yang Maha Esa, atas karunia dan limpahan rahmatNYA jualah Jurnal Informasi dan komputer (JIK) STMIK Dian Cipta Cendikia Kotabumi ini dapat terwujud.Jurnal Informasi dan Komputer (JIK) yang terbit dua (2) kali dalam setahun ini merupakan suatu wadah untuk penyebar luasan hasil-hasil penelitian, studi pustaka, karya ilmiah yang berkaitan dengan Informasi dan Komputer khususnya bagi dosen-dosen STMIK Dian Cipta Cendikia Kotabumi serta umumnya para cendikiawan, praktisi, peneliti ilmu Informatika dan Komputer.

Harapan, dengan diterbitkannya Jurnal Informasi dan Komputer (JIK) ini sebagai salah satu bentuk sumbangan pemikiran dalam pengembangan ilmu informatika dan komputer yang berkaitan dengan kajian-kajian di bidang tekhnologi Informatik, Komunikasi Data dan Jaringan Komputer, perancangan dan Rekayasa Perangkat Lunak, serta ilmu-ilmu yang terkait dengan bidang Informasi dan Komputer lainnya.

Berkenaan dengan harapan tersebut, kepada para peneliti, dosen dan praktisi yang memiliki hasil-hasil penelitian, kajian pustaka, karya ilmiah dalam bidang tersebut diatas, dengan bangga redaksi Jurnal Informasi dan Komputer (JIK) menerima naskah ringkasan untuk dimuat pada jurnal Informasi dan Komputer (JIK) STMIK Dian Cipta Cendikia Kotabumi dengan berpedoman pada penulisan naskah jurnal sebagaimana dilampirkan pada halaman belakang (Bagian kulit dalam) buku jurnal ini.

Mutu dari suatu jurnal ilmiah tidak hanya ditentukan oleh para pengelolanya saja, tetapi para penulis dan pembaca jualah yang mempunyai peranan besar dalam meningkatkan mutu jurnal Informatika dan Komputer ini. Merujuk pada realita ini kamu sangat mengharapkan peran aktif dari peneliti untuk bersama-sama menjaga dan memelihara keberlangsungan dari jurnal Informasi dan Komputer STMIK Dian Cipta Cendikia Kotabumi ini. Yang juga tidak kalah pentingnya dari partisipasi tersebut diatas, adalah saran dan kritik yang membangun dari pembaca yang budiman agar kiranya dapat disampaikan langsung kepada redaksi JIK. Saran dan kritik yang membangun akan dijadikan masukan dan pertimbangan yang sangat berarti guna peningkatan mutu dan kualitas Jurnal Informasi dan Komputer STMIK Dian Cipta Cendikia Kotabumi.

Tak lupa diucapkan terima kasih yang tak terhingga atas perhatian dan kerjasama dari semua pihak yang tak dapat disebutkan satu persatu hingga dapat diterbitkan nya Jurnal Informasi dan Komputer (JIK) STMIK Dian Cipta Cendikia Kotabumi. Semoga apa yang telah diperbuat untuk kebaikan akan menjadi amal ibadah, amin.

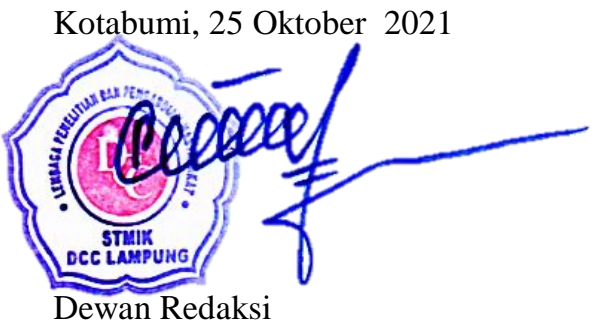




\section{JURNAL INFORMASI DAN KOMPUTER}

Volume 9 Nomor 2 Oktober 2021

\section{Jurnal Informasi dan Komputer merupakan Sarana informasi ilmu} pengetahuan, Tekhnologi dan Komunikasi yang berupa hasil penelitian, tulisan ilmiah, Ataupun studi pustaka. Jurnal ini terbit dua kali setahun pada bulan April dan Oktober. Berisi hasil penelitian ilmiah di bidang informatika yang bertujuan untuk menghubungkan adanya kesenjangan antar kemajuan teknologi dan hasil penelitian. Jurnal ini di terbitkan pertama kali pada tahun 2013.

Penanggung Jawab:

Ketua STMIK Dian Cipta Cendikia Kotabumi

Pembina:

Ketua STMIK Dian Cipta Cendikia Kotabumi Ketua Lembaga Penelitian STMIK Dian Cipta Cendikia Kotabumi

\section{Pimpinan Redaksi}

Dwi Marisa Efendi,.S.Kom.,M.Ti

\section{Redaksi pelaksana}

Rustam,.S.Kom,.M.Ti (STMIK Dian Cipta Cendikia Kotabumi)

Nurmayanti M.Kom (STMIK Dian Cipta Cendikia Kotabumi)

Sukatmi,.S.Kom., M.Kom (AMIK DCC Bandar Lampung)

Sampurna Dadi Riskiono,M.Kom (Universitas Teknokrat Indonesia)

Ifo Wahyu Pratama,S.Kom.,M.Ti(AMIK MASTER Lampung)

\section{Mitra Bestari}

Dr. RZ. ABDUL AZIZ, ST., MT (Institut Informatika dan Bisnis Darmajaya)

Dr. Dadang Sudrajat, S.Si, M.Kom (STMIK IKMI Cirebon)

Dr. Septafiansyah Dwi Putra, S.T., M.T (Politeknik Negeri Lampung)

Dr. Evi Grativiani, S.E., M.S.I (Universitas Sebelas Maret)

Rohmat Indra Borman ( Universitas Teknokrat Indonesia )

Ferry Wongso, S.KOm., M.Kom ( STMIK Darma Pala Riau)

Ferly Ardhy, S.Kom., M.Ti ( Universitas Aisyah Pringsewu )

Firmansyah, S.E., M.Si (STMIK Darma Pala Riau)
Amarudin (Universitas Teknokrat Indonesia)

Didi Susianto, S.T., M.Kom (AMIK Dian Cipta Cendika Bandar Lampung)

Alhibarsyah, St., M.Kom (STMIK Tunas

Bangsa Bandar Lampung)

Kemal Farouq Mauladi, S.Kom .M.Kom (Universitas Islam Lamongan)

Rima Mawarni, M.Kom ( STMIK Dian Cipta Cendikia Kotabumi)

Wira Jaya Hartono, S.Pd., M.Pd ( STMIK Darma Pala Riau)

Penerbit : STMIK Dian Cipta Cendikia Kotabumi Bekerja Sama Dengan LPPM STMIK Dian Cipta Cendikia Kotabumi.

\section{Alamat Redaksi/Penerbit:}

Jl. Negara No. 3 Candimas Kotabumi Lampung Utara

No Telpon/Fax 072423003

Email : 1ppm-stmik@dcc.ac.id 


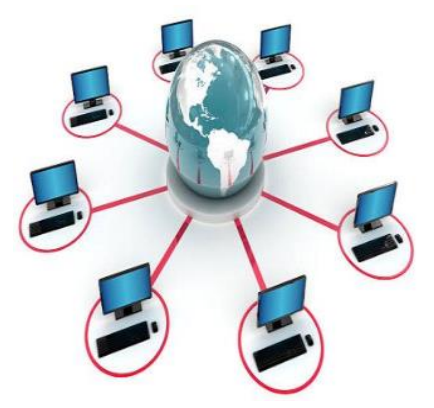

\section{JURNAL INFORMASI DAN KOMPUTER VOL. 9 NO. 2 THN. 2021}

\section{DAFTAR ISI}

Halaman

Sistem Informasi Akuntansi Persedian Barang Berbasis Web Pada Lembaga

Permasyarakatan Kelas II A Banceuy Bandung : "Kelompok Tani Desa Banjar Kertarahayu” Teuku Rian Hardiyansyah, Fatia Salsa Azzahra (Politeknik Piksi Ganesha Bandung ${ }^{1,2}$ )

Penerapan Finite State Automata Pada Vending Machine Penjual Obat Non Resep

Dokter Dan Keperluan Medis

Eko Supriyanto $^{1}$, Angga Ardiansyah ${ }^{2}$, Frieyadie $^{3}$, Sri Rahayu ${ }^{4}$, Windu Gata ${ }^{5}$

(Universitas Nusa Mandiri ${ }^{12}$ )

Sistem Pendukung Keputusan Untuk Menentukan Kelayakan Pengajuan Sertifikasi Guru Dengan Metode Simple Additive Weighting (Studi Kasus : Ma Al Muhajirin Janti Jogoroto Jombang)

Budiman, umam baharudin, winarti

(Universitas Darul 'Ulum Jombang)

Perancangan Infrastruktur Domain Name Server Lokal Menggunakan Ubuntu Server 16.04

Pada PT. Xyz

Zaenal Mutaqin Subekti, Hendra Setiawan, Satria, Widia Murni Wijaya,

Aliy Hafiz, Warsudi

(STMIK Bani Saleh, Universitas Negeri Yogyakarta, AMIK Dian Cipta Cendikia,

STMIK MIC CIkarang)

Perancangan Sistem Informasi Idea Proposal (Ip) Berbasis Web Pada Pt. Paxel Algorita Unggul

Julian Murhan Sahputra, Indah Purnamasari

(Universitas Nusa Mandiri ${ }^{12}$ )

Sistem Pendukung Keputusan Untuk Menentukan Ekstrakurikuler Atletik

Berdasarkan Bakat Siswa Menggunakan Metode Profile Matching

Agnes Basuki, Petrus Sokibi, Tiara Eka Putri

(Universitas Catur Insan Cendekia)

Penerapan Algoritma K-Means Untuk Pengelompokan Usia Calon Penerima Vaksin

Di Kab. Ngawi

Irna Yuniarfi, Saifulloh

(Universitas PGRI Madiun ${ }^{12}$ )

System Penilaian Seleksi Calon Karyawan Baru Menggunakan Metode Simple Additive

ISTMIK Dian Cipta Cendikia Kotabumi 
Weighting (SAW) Di PT.TNA

Anik Sri Wahyuningsih, Yudhi Firmansyah

(Universitas Panca Sakti Bekasi )

Perancangan Sistem Informasi Pembayaran SPP Menggunakan Framework Laravel

Ichwan Habib Moudi

(Universitas Panca Sakti Bekasi)

Implementasi Algoritma K-Means Dan Algoritma Apriori Optimasi Kinerja Ecu

(Study Kasus Mobil Avanza Dan Xenia)

Sigit Mintoro' Asep Afandi

(STMIK Dian Cipta Cendikia Kotabumi)

Sistem Pakar Penyakit Buah Kakao Untuk Peningkatan Hasil Panen Kakao Menggunakan

Metode Case Base Reasoning (CBR) Berbasis Web Mobile

Aliy hafiz, Verawati

(AMIK Dian Cipta Cendikia,Bandar Lampung)

Penerapan Metode Rapid Application Develomment (RAD) Dalam Pengembangan

Sistem Pemesanan Menu Berbasis Android

Aris Baihaqi, Tumini

(Fakultas Sains dan Teknologi ${ }^{1,2}$ )

Rancang Bangun Sistem Informasi Geografis Pariwisata Di Lampung Timur

Sukatmi, Rexa Alfa Rizi

(AMIK DCC Bandar Lampung ${ }^{12}$ )

Implementasi Psak No. 45 Pada Proses Penyusunan Laporan Keuangan Menggunakan

M.S. Excel Dan Aplikasi Accurate Accouting Pada STMIK Bani Saleh

Marhakim, Willy Adam

$\left(\right.$ STMIK Bani Saleh ${ }^{12}$ )

Sistem Prediksi Harga KOPI LAMBAR ( Lampung Barat) Dengan Metode

Backpropagation, dan Double Exponential ( Studi Kasus BUMDES )

Supriyanto, Dwi marisa Efendi,Rhomadhon

(STMIK Dian Cipta cendikia Kotabumi ${ }^{1-}$ )

Sistem Informasi Pemasaran Produk Umkm Berbasis Web Pada Kecamatan Bumi

Nabung Lampung Tengah

Yuli Syafitri, Agus Prasetyo, Reni Astika

(AMIK Dian Cipta Cendikia Bandar Lampung)

Rancang Bangun Aplikasi Pembelajaran Aksara Lampung Berbasis Android

Ferly Ardhy, Hendra Syahrobi

(Universitas Aisyah Pringewu ${ }^{1,}$ STMIK Dian Cipta Cendikia ${ }^{2}$ )

Sistem Pakar Diagnosa Penyakit Kulit Pada Balita Menggunakan Metode Naïve

Bayes Dan Forward Chaining Studi Kasus Puskesmas Cempaka Sungkai Selatan

Sidik Rahmatullah, Rima Mawarni

(STMIK Dian Cipta Cendikia Kotabumi ${ }^{12}$ )

Rekayasa Perangkat Lunak Perhitungan Harga Pokok Produksi Metode

Full Costing Pada Umkm Mitra Cake Di Bandar Lampung

Pitrawati, Arif Sanjaya

$$
\text { ISTMIK Dian Cipta Cendikia Kotabumi }
$$


Rancang Bangun Sistem Ujian Online Menggunakan Algoritma Cosine Similarity Berbasis Web

Haryono, Zaenal Mutaqin Subekti, Widiyawati, Hidayatullah (STMIK Bani Saleh ${ }^{1234}$ )

Model Aplikasi Helpdesk Ticketing System Berbasis Web Menggunakan Metode Rad Indra Permana

Pattern Recognition Tulisan Tangan Huruf Hijaiyah Menggunakan Metode Convolutional Neural Network (CNN)

Mufassiril Abror, Nopiyanto

(Universitas Panca Sakti Bekasi ${ }^{12}$ )

Aplikasi Sistem Informasi Keuangan Berbasis Android Di Perumahan Taman

Karang Bahagia

Melda Ayulestari

(Universitas Panca Sakti Bekasi)

Audit Pelayanan Sistem Rujukan Online Puskesmas Menggunakan Framework COBIT 5.0

Nurmayanti, Merri Parida, Ngajiyanto, Ina Anzalna

(STMIK Dian Cipta Cendikia Kotabumi ${ }^{1234}$ )

Perancangan Sistem Informasi Pengolahan Data Nilai Siswa Berbasis Web

Erin Ermawati, Anik Sri Wahyuningsih

(Fakultas Sain dan Teknologi, Universitas Panca Sakti Bekasi ${ }^{12}$ )

Pengembangan Sistem Pelaporan Data Hasil Inspeksi Barang Berbasis Web

Siska Putriani

(Universitas Pancasakti Bekasi)

Penerapan Extreme Programming Dalam Perancangan Aplikasi Web Food Market

Tumini, Hilman Septiana

(Fakultas Sains dan Teknologi Universitas Panca Sakti Bekasi ${ }^{1,2}$ )

Sistem Pencarian Barang Berbasis Website Menggunakan Php Dan Mysql

Studi Kasus PT. Surya Technology Industri

Sulaeman

(Universitas Panca Sakti Bekasi)

Implementasi Metode Prototype Pada Sistem Peminjaman Alat Kerja Berbasis Web

Di PT SK Metalindo

Ali Mulyanto, Arjun Gunawan

(Univeritas Panca Sakti Bekasi)

Aplikasi Tata Cara Wudhu Menggunakan Teknologi Augmented Reality

Sebagai Media Pembelajaran

Di TK Al Fatih

Ahmad Yakub, Idarul Fadli

(Universitas Panca Sakti Bekasi ${ }^{12}$ ) 
Sistem Pakar Diagnosa Penyakit Ayam Petelur Menggunakan Metode Certainty Factor Berbasis Web

Mochammad Taufiq Hidayat, Ali Mulyanto

(Universitas Panca Sakti Bekasi ${ }^{12}$ ) $148-155$

Penerapan Metode Prototyping Dalam Perhitungan Hasil Produksi Menggunakan Arduino Uno R3 Dan Php Di PT. Indonesia Epson Industry

Amandha Aulia, Ajar Rohmanu

(Universitas Panca Sakti Bekasi ${ }^{12}$ )

System Pendukung Keputusan Penentuan Guru Teladan Dengan Metode Profile Matching

Hasbulloh, Agmawarnida

(Universitas Panca Sakti Bekasi ${ }^{1,2}$ )

Implementasi Waterfall Method Pada Aplikasi Buku Induk Siswa Berbasis Web

Idam Holid, Yogie Krisnayadi

(Universitas Panca Sakti ${ }^{12}$ )

Pengembangan Text To Speech Media Pembelajaran Untuk Pengenalan

Anggota Tubuh Manusia Kelas V Sekolah Dasar

Juwanda Saputra, Ali Mulianto

(Teknik Infomratika Fakulutas Sains dan Teknologi ${ }^{12}$ )

Perancangan Sistem Peminjaman Barang Berupa Aset Tetap Berbasis Web

Pada Lembaga Permasyarakatan Kelas II A Banceuy Bandung

Guntur Salasa Priambodo, Perwito, Candra Mecca Sufyana

(Politeknik Piksi Ganesha Bandung ${ }^{1,2,3}$ )

Metode Pemilihan Karyawan Terbaik Sebagai Penentu Goodwill Perguruan Tinggi

Dengan Menggunakan Metode Topsis (Studi Kasus Perguruan Tinggi Di Lampung Utara)

Dwi Sartika, Pakarti Riswanto

(STMIK Dian Cipta Cendikia Kotabumi)

Sistem Pendukung Keputusan Pemilihan Merek Smartphone Menggunakan

Metode Analytical Hierarchy Process (AHP)

Ade Kiki Fatmawati, Muhammad Sultan Raflie, Norma Yunita

(Universitas Nusa Mandiri ${ }^{123}$ )

Pattern Recognition Aksara Lampung Menggunakan Algoritma Neural Network

Metode Analytical Hierarchy Process (AHP)

Nopiyanto, Rahmadi

(Universitas Panca Sakti Bekasi) 116-121 


\title{
PENERAPAN FINITE STATE AUTOMATA PADA VENDING MACHINE PENJUAL OBAT NON RESEP DOKTER DAN KEPERLUAN MEDIS
}

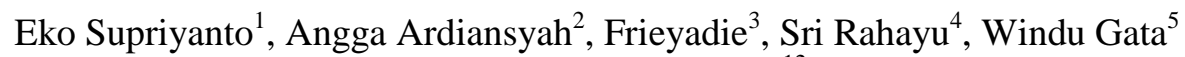 \\ Universitas Nusa Mandiri ${ }^{12}$ \\ Jalan Kramat Raya No.18,Senen, Jakarta Pusat \\ Emails: 14207050@nusamandiri.ac.id ${ }^{1}, 14207006 @$ nusamandiri.ac.id ${ }^{2}$, \\ frieyadie@nusamandiri.ac.id ${ }^{3}$, srirahayu.rry@nusamandiri.ac.id ${ }^{4}$,windu@nusamandiri.ac.id $^{5}$
}

\begin{abstract}
ABSTRAK
Kebutuhan obat non resep dokter dan keperluan medis menjadi salah satu kebutuhan yang sangat penting untuk dipenuhi dengan mudah,cepat, tepat, dan aman bagi masyarakat saat ini, beragamnya pilihan obat yang dijual mengharuskan masyarakat mampu memilih dengan cermat dan tepat dalam membeli obat sesuai dengan kebutuhan penyakit yang dialami,informasi tentang kandungan, aturan pakai dan efek samping dari obat juga sangat penting untuk diketahui masyarakat guna memaksimalkan maanfaat dari obat yang dikonsumsi. Sistem penjualan obat yang tersedia saat ini adalah dengan penjualan langsung di apotek, toko kelontong dan secara daring yang memiliki keterbatasan dalam sebaran ketersedian toko dan waktu pelayanan yang terbatas. Penelitian ini bertujuan untuk memberikan alternatif sistem penjualan obat non resep dokter dan keperluan medis dengan memanfaatkan perkembangan teknologi vending machine (VM) menggunakan finite state automata (FSA model Non-deterministic Finite Automata (NFA)). Dengan kelebihan penjualan menggunakan VM yang dapat diletakan dimana saja dan dapat beroperasi kapan saja membuat penjualan dengan sistem ini dapat tersedia kapanpun dan dimanapun untuk memenuhi kebutuhan obat dan keperluan medis bagi masyarakat yang mendesak dengan mudah,cepat, tepat, dan aman. Metode yang diterapkan dalam Penerapan FSA pada VM Penjual Obat Non Resep Dokter dan Keperluan Medis ini antara lain Finite State Automata VM Obat Non Resep Dokter dan Keperluan Medis, Perancangan Sistem VM Obat Non Resep Dokter dan Keperluan Medis, dan Desain VM Obat Non Resep Dokter dan Keperluan Medis. Berdasarkan perancangan FSA VM diatas, dihasilkan VM Penjual Obat Non Resep Dokter dan Keperluan Medis yang dapat diletakan dimana saja dan tersedia kapan saja, sehingga dapat disimpulkan penggunaan finite state automata (FSA) model Nondeterministic Finite Automata (NFA) dapat dimanfaatkan dalam pembuatan VM Penjual Obat Non Resep Dokter dan Keperluan Medis dengan menyediakan menu pilihan metode pembayaran tunai dan non tunai, kebutuhan akan obat dan keperluan medis yang mendesak bagi masyarakat dapat terpenuhi dengan mudah, cepat, tepat dan aman.
\end{abstract}

Kata Kunci : Vending Machine, Finite State Automata, Obat Non Resep

\section{ABSTRACTS}

The need for non-prescription drugs and medical needs is one of the most important needs to be fulfilled easily, quickly, precisely, and safely for today's society, the wide selection of drugs sold requires people to be able to choose carefully and precisely in buying drugs according to their needs The disease experienced, information about the content, rules of use and side effects of the drug is also very important for the public to know in order to maximize the benefits of the drugs consumed. The currently available drug sales system is direct sales at pharmacies, grocery stores and online which have limitations in the distribution of store availability and limited service time. This study aims to provide an alternative system for selling non-prescription drugs and medical needs by utilizing the development of vending machine (VM) technology using finite state automata (FSA model Non-deterministic Finite Automata (NFA)). With 
the advantages of selling using a VM that can be placed anywhere and can operate at any time, making sales with this system available anytime and anywhere to meet the urgent needs of medicine and medical needs for the community easily, quickly, precisely, and safely. The methods applied in the application of FSA to VMs selling non-prescription drugs and medical needs include Finite State Automata VMs for non-prescription drugs and medical needs, system design for VMs for non-prescription drugs and medical needs, and design of VMs for non-prescription drugs and medical supplies. Medical Needs. Based on the design of the FSA VM above, a VM of Non-Prescription Drug Sellers and Medical Needs is produced which can be placed anywhere and available at any time, so it can be concluded that the use of finite state automata (FSA) Non-deterministic Finite Automata (NFA) models can be utilized in making VMs Seller of Non Prescription Drugs and Medical Needs by providing a menu of cash and non-cash payment methods, the need for drugs and urgent medical needs for the community can be met easily, quickly, precisely and safely.

Key Word: Vending Machine, Finite State Automata, Non Prescription Drugs

\section{PENDAHULUAN}

Obat dan keperluan medis merupakan salah satu kebutuhan yang penting bagi manusia, berbagai jenis pilihan obat dan keperluan medis saat ini banyak tersedia, sehingga diperlukan pertimbangan dan pengetahuan yang cermat dalam memilih obat untuk suatu penyakit, tidak kalah penting, obat harus digunakan secara benar sesuai anjuran agar memberikan manfaat yang maksimal. Terlalu banyaknya jenis obat dengan informasi yang minim ternyata juga dapat memberikan masalah tersendiri terutama menyangkut bagaimana memilih dan menggunakan obat secara benar dan aman.

Sistem pembelian obat dan keperluan medis saat ini dilakukan dengan penjualan secara langsung datang ke toko obat baik apotek atau toko kelontong maupun memesan secara daring dengan kelebihan dan kekurangan masingmasing, untuk pembelian obat dan keperluan medis di apotek jenis obat dan keperluan medis sangat lengkap serta pembeli dapat menanyakan informasi terkait kandungan obat dan aturan penggunaannya kepada apoteker yang pengetahuannya terhadap obat dapat menjamin penggunaan obat dan keperluan medis secara tepat,tetapi jumlah apotek dan jam oprerasionalnya cukup terbatas sehingga tidak dapat tersedia untuk waktu yang mendesak, untuk pembelian obat dan keperluan medis di toko kelontong jenis obatnya dan keperluan medis terbatas, penjual tidak memiliki pengetahuan yang cukup terhadap kandungan,aturan penggunaan dan efek samping dari obat sehingga manfaat dari obat tidak didapat secara maksimal atau bahkan dapat membahayakan, walaupun harganya murah. Untuk pembelian obat dan keperluan medis secara daring dengan jenis dan harga yang bersaing tetapi keaslian obat serta waktu kedatangan obat tidak dapat dijamin kepastiannya sehingga tidak dapat digunakan saat mendesak.

Penelitian ini mencoba memberikan alternatif penjualan obat non resep dokter dan keperluan medis dengan memanfaatkan perkembangan teknologi vending machine (VM) menggunakan finite state automata (FSA). Dengan kelebihan VM dapat diletakan dimana saja dan dapat beroperasi kapan saja membuat penjualan dengan sistem ini dapat tersedia kapanpun dan dimanapun untuk memenuhi kebutuhan obat dan keperluan medis bagi masyarakat yang mendesak.

Obat adalah semua bahan tunggal atau campuran yang digunakan oleh semua makhluk untuk bagian dalam maupun bagian luar, guna mencegah, meringankan, maupun menyembuhkan penyakit [1], dalam penggolongannya obat dibagi tiga jenis golongan obat yaitu obat bebas, obat bebas terbatas dan obat keras [2]. Obat bebas merupakan obat yang dapat dibeli dipasaran tanpa mengunakan resep, ditandai dengan lingkaran berwarna hijau dengan garis tepi berwarna hitam, seperti gambar 1

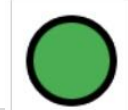

9 ISTMIK Dian Cipta Cendikia Kotabum i 


\section{Gambar 1.Tanda Obat Bebas}

obat bebas terbatas merupakan obat yang dapat dibeli dipasaran tanpa mengunakan resep dokter tapi disertai tanda peringatan tanda khusus untuk obat ini adalah lingkaran warna biru dengan garis tepi berwarna hitam, seperti gambar 2

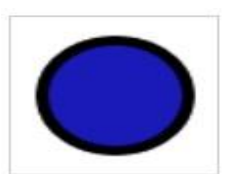

Gambar 2.Tanda Obat Bebas Terbatas

untuk obat bebas terbatas diberi pula tanda peringatan,seperti gambar 3

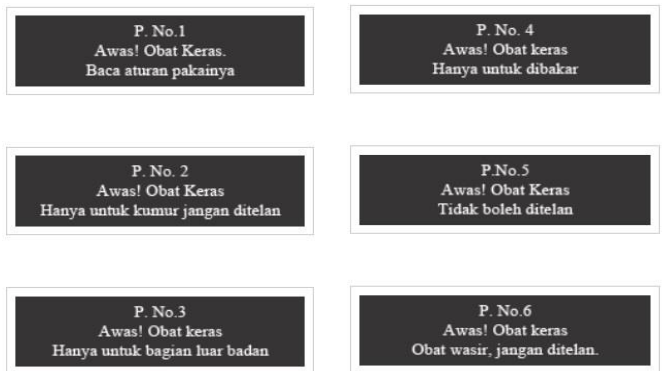

Gambar 3.Tanda Peringatan Obat Bebas Terbatas

Obat keras merupakan obat yang hanya bias didapatkan dengan resep dokter, obat ini ditandai dengan lingkaran bulat berwarna merah dengan garis tepi berwarna hitam,dengan huruf $\mathrm{K}$ ditengah yang menyentuh garis tepi, seperti gambar 4

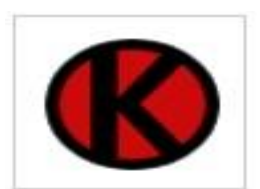

Gambar 4.Tanda Obat Keras

Teknologi informasi yang semakin berkembang merubah sebagian besar gaya hidup masyarakat terutama di Indonesia yang awalnya tradisional menjadi modern. Berbagai inovasi yang mengarah pada penggunaan alat yang membuat pekerjaan menjadi semakin efisien, praktis, aman, cepat dan nyaman. Penggunaan teknologi dalam bidang industri yaitu mesin otomatis yang bertujuan untuk mengubah kegiatan yang bersifat manual menjadi otomatis terutama untuk mempercepat menghasilkan produk yang berkualitas [3]. Vending Machine (VM) adalah perangkat yang digunakan di berbagai tempat untuk menyimpan dan mengeluarkan berbagai jenis barang dagangan, termasuk minuman dan makanan ringan. Hal ini sebagai respon atas permintaan pelanggan dan pembayaran yang sesuai. VM memberikan banyak manfaat bagi pelanggan dan operator. VM biasanya menyediakan layanan yang nyaman untuk pelanggan dan akses dua puluh empat jam. Beberapa VM otomatis dirancang untuk menjual rokok dan koran. Sejumlah VM sering ditempatkan di tempat umum, seperti di tempat transit perjalanan [4]. Luasnya bidang dalam teknologi informasi tak lepas dari penerapan teori bahasa dan automata yang mendasari pengembangan teknologi komputasi, Finite State Automata (FSA) merupakan model komputasi paling sederhana hanya dengan memori yang sangat terbatas, tetapi walaupun dengan keterbatasan memory tersebut, FSA dapat melakukan sesuatu yang bermanfaat sebagai inti dari peralatan elektromekanik [5], FSA terdiri dari dua jenis yaitu Deterministic Finite Automata (DFA) dan Non-deterministic Finite Automata (NFA). Yang membedakan keduanya adalah DFA hanya memiliki satu arah transisi state saja, sedangkan pada NFA dapat memiliki lebih dari satu arah transisi state[6].

Dalam penelitian sebelumnya konsep penjualan produk dengan VM digunakan dalam penjualan produk rujak buah yang berhasil memperluas penjualan produk ke beberapa lokasi [7], pada penelitian penjualan jamu tradisional FSA digunakan sebagai logika dasar dalam proses penjualan dengan menerima berbagai macam inputan dan mengeluarkan produk sesuai dengan pilihan serta melakukan pengembalian uang dari kelebihan pembayaran secara tunai [8], pada penelitian penjualan rokok konsep VM dengan logika FSA dapat dimanfaatkan dalam penyediaan sistem pembayaran secara tunai dan non tunai sehingga memudahkan pengguna dalam bertransaksi [9]. Di Indonesia banyak penelitian tentang penjualan obat,namun hanya sebatas sistem aplikasi penjualan obat saja dimana teknis penjualanya tetap dilakukan secara manual [10]-[12]. Pada penelitian mesin penjual obat otomatis dengan resep dokter, pengguna diharuskan membawa resep dokter yang selanjutnya resep itu akan dipindai pada VM dan obat akan keluar sesuai dengan resep yang dipindai [13]. 
Dalam penelitian ini yang menjadi fokus adalah penjualan obat non resep dokter kategori obat bebas dan obat bebas terbatas menggunakan VM untuk beberapa penyakit ringan seperti pusing dan demam, batuk, maag, sakit gigi, diare, luka luar, dan vitamin, serta keperluan medis sederhana seperti perban, masker, termometer, testpack, vitamin, antibiotik, handsanitizer dan lain-lain, dan dilengkapi dengan informasi terkait kandungan, aturan penggunaan serta efek samping dan rekomendasi obat bagi pengguna, sehingga pengguna mendapat manfaat yang maksimal dan tepat dari obat atas penyakit yang dialam. Sistem pembayaran yang disediakan pada penjualan vending machine ini ada dua yaitu secara tunai dan non tunai, untuk pembayaran secara tunai, pengguna dapat memasukan uang tunai sedangkan non tunai dengan menggunakan kartu, dengan sistem pembayaran ini akan mempermudah pengguna dalam melakukan pembelian obat di mesin penjual otomatis ini, dengan segala kelebihan dari penjualan obat menggunakan mesin penjual otomatis, diharapkan kebutuhan masyarakat akan obat dan keperluan medis dapat terpenuhi dengan mudah, cepat, tepat dan aman.

\section{METODE PENELITIAN}

Metode yang diterapkan dalam Penerapan FSA pada VM Penjual Obat Non Resep Dokter dan Keperluan Medis antara lain Finite State Automata VM Obat Non Resep Dokter dan Keperluan Medis, Perancangan Sistem VM Obat Non Resep Dokter dan Keperluan Medis,

Gambar 5. FSA VM Penjual Obat Non Resep Dokter dan Keperluan Medis

Finite State Automata VM Penjual Obat Non Resep Dokter dan Keperluan Medis

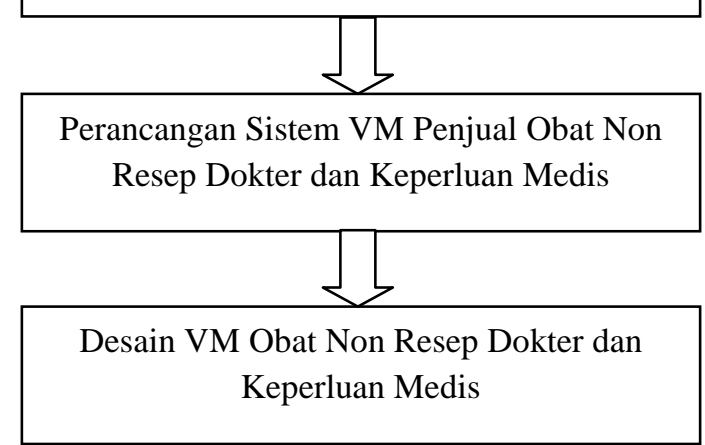

Desain VM Obat Non Resep Dokter dan Keperluan Medis, seperti terlihat pada gambar 5

1. Finite State Automata VM Penjual Obat Non Resep Dokter dan Keperluan Medis

Pada tahap ini dilakukan penggambaran FSA menggunakan konsep Non-deterministic Finite Automata (NFA)

2. Perancangan Sistem VM Penjual Obat Non Resep Dokter dan Keperluan Medis

Pada tahap ini sistem dirancang menggunakan Unified Modeling Language (UML), pendeskripsian alur aktivitas sistem untuk menjelaskan fungsi dari sistem dan interaksinya menggunakan use case diagram dan activity diagram

3. Desain VM Penjual Obat Non Resep Dokter dan Keperluan Medis

Pada tahap ini dilakukan perancangan desain antarmuka dari VM penjual obat non resep dokter dan keperluan medis saat pengimplementasiannya.

\section{HASIL DAN PEMBAHASAN}

Berdasarkan metode penelitian yang sudah diterapkan hasil dan pembahasannya adalah sebagai berikut :

\subsection{Perancangan FSA VM Penjual Obat Non Resep Dokter dan Keperluan Medis}

Perancangan FSA menggunakan model Nondeterministic Finite Automata (NFA) dimana alurnya seperti terlihat pada Gambar 6 .

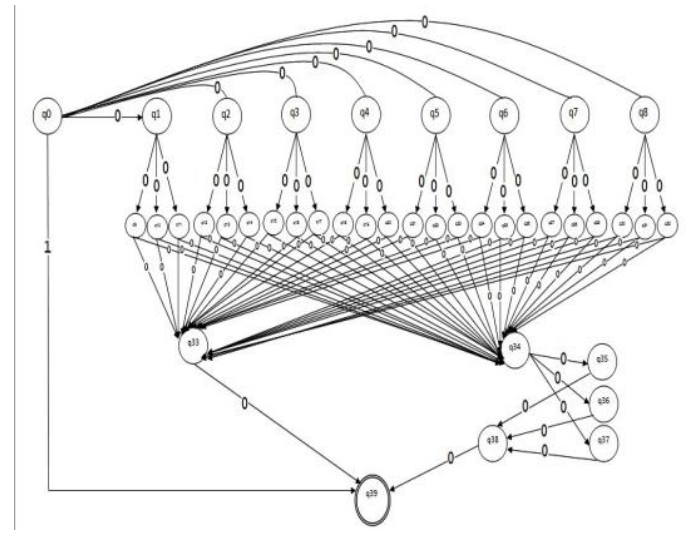

Pada diagram state diatas, konfigurasi FSA dapat dijelaskan sebagai berikut.

$\mathrm{Q}=\{\mathrm{q} 0, \mathrm{q} 1, \mathrm{q} 2, \mathrm{q} 3, \mathrm{q} 4, \mathrm{q} 5, \mathrm{q} 6, \mathrm{q} 7, \mathrm{q} 8, \mathrm{q} 9, \mathrm{q} 10, \mathrm{q} 11, \mathrm{q} 12$ 


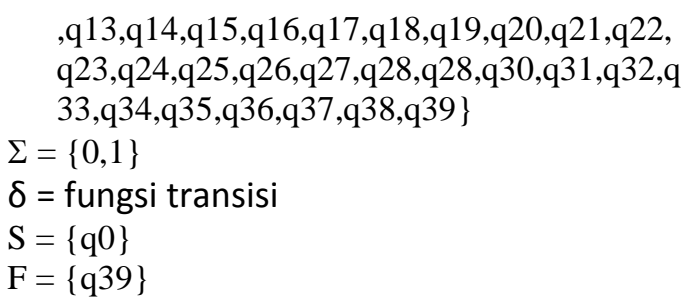

Konfigurasi mesin tesebut memiliki beberapa simbol state yang menyimbolkan suatu proses sebagai yang diterangkan pada Tabel 1 .

Tabel 1. Deskripsi State

\begin{tabular}{|c|l|}
\hline State & \multicolumn{1}{|c|}{ Deskripsi } \\
\hline q0 & state awal \\
\hline q1 & Obat Pusing dan demam \\
\hline q2 & Obat Batuk \\
\hline q3 & Obat Maag \\
\hline q4 & Obat Sakit Gigi \\
\hline q5 & Obat Diare \\
\hline q6 & Obat Luka Luar \\
\hline q7 & Vitamin \\
\hline q8 & Keperluan Medis \\
\hline q9 & Paracetamol \\
\hline q10 & Aspirin \\
\hline q11 & Ibuprofen \\
\hline q12 & Dekongestan \\
\hline q13 & Supresan \\
\hline q14 & Ekspektoran \\
\hline q15 & Promag \\
\hline q16 & Mylanta \\
\hline q17 & Waisan \\
\hline q18 & Ponstan \\
\hline q19 & dentasol \\
\hline q20 & Super Green Plus SG \\
\hline q21 & Loperamide (Imodium) \\
\hline q22 & Attapulgite \\
\hline q23 & Bismuth subsalicylate \\
\hline q24 & Hydrocolloid \\
\hline q25 & Hydrogel \\
\hline q26 & Alginat \\
\hline q27 & Imboost \\
\hline q28 & Astria \\
\hline q29 & Holisticare Ester C 4 Tablet \\
\hline q30 & Plester Luka \\
\hline q31 & Handsanitizer \\
\hline q32 & Pembalut \\
\hline q33 & Pembayaran no tunai \\
\hline q34 & Pembayaran tuna \\
\hline
\end{tabular}

\begin{tabular}{|l|l|}
\hline q35 & Uang tunai pecahan Rp.5.000 \\
\hline q36 & Uang tunai pecahan Rp.10.000 \\
\hline q37 & Uang tunai pecahan Rp.20.000 \\
\hline q38 & Total Pembayaran tunai \\
\hline q39 & State akhir \\
\hline \multicolumn{2}{|c|}{ Tabel 2. Himpunan Masukan }
\end{tabular}

\begin{tabular}{|c|c|}
\hline inputan $(\Sigma)$ & Deskripsi \\
\hline 0 & $\begin{array}{c}\text { Lanjut menuju state } \\
\text { berikutnya }\end{array}$ \\
\hline 1 & Mesin menyesaikan tugasnya \\
\hline
\end{tabular}

Kemudian dilakukan contoh ujicoba memberikan masukan kepada state hingga state akhir mesin mengeluarkan obat yang dipilih, seperti telihat pada Tabel 3.

Tabel 3. Ujicoba Transisi Negasi

\begin{tabular}{|c|c|c|c|c|}
\hline$\delta$ & 0 & 0 & 0 & 0 \\
\hline $\mathrm{q} 0$ & $\mathrm{q} 1$ & $\mathrm{q} 9$ & $\mathrm{q} 33$ & $\mathrm{q} 39$ \\
\hline & & & & \\
\hline
\end{tabular}

Pada rancangan diagram FSA di atas q0 merupakan state awal dan q39 merupakan state akhir, state akan menerima masukan berupa satu dan nol, dimana masukan nol, artinya state akan menuju ke state berikutnya, dan jika memerima masukan satu maka state akan berhenti dan mesin akan menyelesaikan tugas dengan mengeluarkan obat atau keperluan medis sesuai dengan pilihan dan kembali ke state awal. Rancangan diagram di atas juga memiliki masukan khusus dalam metode pembayaran tunai berupa pecahan uang Rp.5.000; Rp.10.000; Rp.20.000; dan non tunai berupa kartu e-money.

Pada state awal q0 pengguna diminta untuk memilih jenis penyakit yang diderita terdapat beberapa pilihan (state q1-q8) diantaranya: pusing dan demam, batuk, maag, sakit gigi, diare, luka luar, dan vitamin serta pilihan keperluan medis ,misalkan pengguna memillih obat pusing maka mesin akan menampilkan beberapa pilihan untuk obat pusing seperti Paracetamol,Aspirin, dan Ibuprofen pilihan obat akan disertai kandungan, kegunaan, aturan pakai dan efek samping dari masing-masing obat setelah memilih jenis obat yang diinginkan maka state akan menuju kepada state pemilihan jenis pembayaran, mesin menyediakan pilihan metode pembayaran tunai (q34) dan non tunai dengan menempelkan kartu e-money (q33) jika pembayaran baik tunai maupun non tunai telah 
terkonfirmasi maka akan menuju ke state akhir (q39) dimana mesin akan memgeluarkan obat sesuai dengan pilihan.

\subsection{Perancangan Sistem VM Penjual Obat Non Resep Dokter dan Keperluan Medis}

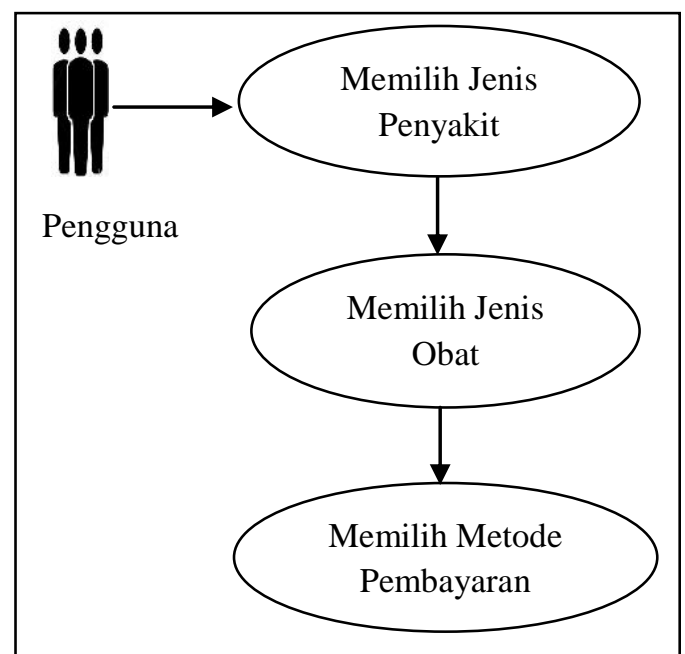

Gambar 7. Use Case Diagram VM Penjual Obat

Non Resep Dokter dan Keperluan Medis

Pada Gambar 7 Use Case Diagram VM Penjual Obat Non Resep Dokter dan Keperluan Medis menjelaskan use case diagram dengan pengguna yang dapat memilih jenis penyakit setelah itu memilih jenis obat dari penyakit yang dipilih, kemudian pengguna dapat memilih metode pembayaran menggunakan uang tunai atau non tunai.

\subsection{Desain VM Penjual Obat Non Resep Dokter dan Keperluan Medis}

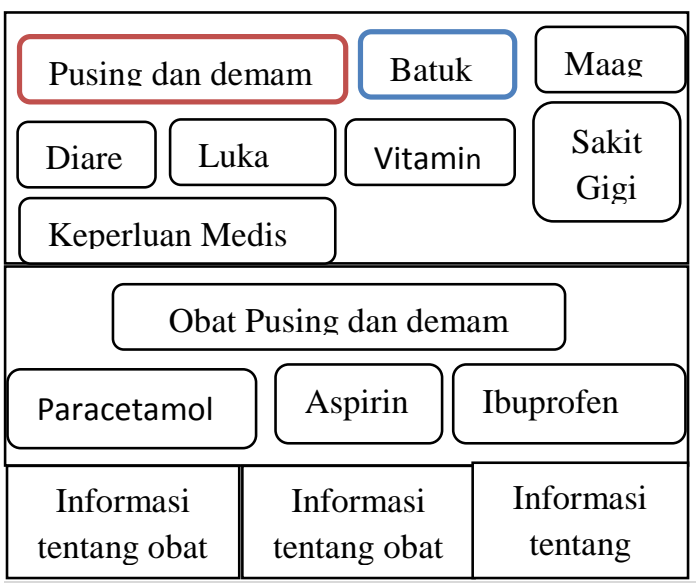

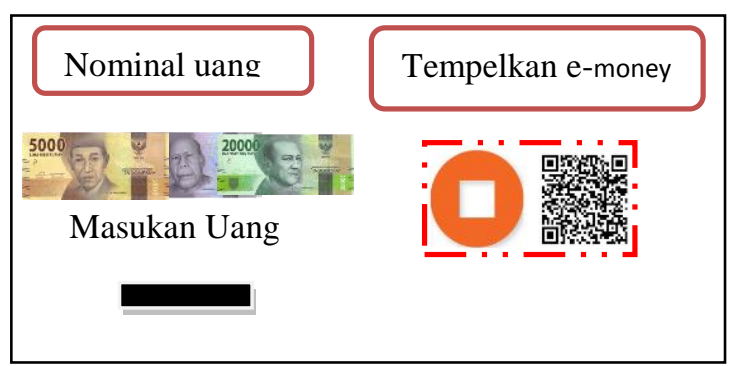

Gambar 8. Desain Antarmuka VM Penjual Obat Non Resep Dokter dan Keperluan Medis

Gambar 8. merupakan desain tampilan antar muka VM Penjual Obat Non Resep Dokter dan Keperluan Medis dengan proses kerja diawali dengan tampilan menu jenis penyakit lalu pengguna memilih jenis penyakit yang diderita diantaranya: pusing dan demam, batuk, maag, sakit gigi, diare, luka luar, dan vitamin serta pilihan keperluan medis dan selanjutnya VM akan menamilkan pilihan beberapa jenis obat yang dapat dipilih untuk penyakit tersebut disertai dengan informasi terkait kandungan, kegunaan, aturan pakai dan efek samping dari masing-masing obat, setelah memilih jenis obat akan menuju pemilihan jenis pembayaran disediakan pilihan metode pembayaran tunai dengan pecahan uang 5.000, $10.000,20.000$ dan untuk pembayaran non tunai, VM akan menampilkan menu untuk menempelkan kartu e-money, selanjutnya VM akan mengeluarkan obat sesuai piihan setelah pembayaran terkonfirmasi.

\section{KESIMPULAN}

Berdasarkan perancangan FSA VM diatas, dihasilkan VM Penjual Obat Non Resep Dokter dan Keperluan Medis yang dapat diletakan dimana saja dan tersedia kapan saja, sehingga dapat disimpulkan penggunaan finite state automata (FSA) model Non-deterministic Finite Automata (NFA) dapat dimanfaatkan dalam pembuatan VM Penjual Obat Non Resep Dokter dan Keperluan Medis dengan menyediakan menu pilihan metode pembayaran tunai dan non tunai, kebutuhan akan obat dan keperluan medis yang mendesak bagi masyarakat dapat terpenuhi dengan mudah, cepat, tepat dan aman. Saran untuk penelitian selanjutnya adalah mengembangkan system kembalian untuk pembayaran secara tunai dan fasilitas isi saldo 
untuk e-money serta penambahan jenis obat.

\section{DAFTAR PUSTAKA}

[1]"Farmasetika Dasar \& Hitungan Farmasi Google Books." https://www.google.co.id/books/editi on/Farmasetika_Dasar_Hitungan_Far masi/rLWvvfL8-

$\mathrm{BcC}$ ?hl=id\&gbpv=1\&dq=ilmu+resep +syamsuni+2005\&pg=PA16\&printse $\mathrm{c}=$ frontcover (accessed Jun. 03, 2021).

[2] "PEDOMAN UMUM | PIO Nas." http://pionas.pom.go.id/ioni/pedoman -umum.

[3] Fergie Joanda Kaunang, "Penerapan Konsep Finite State Automata ( FSA ) pada Mesin The Implementation of Finite State Automata in an Automatic Ice cream Maker Machine," Penerapan Konsep Finite State Autom. pada Mesin Pembuat Ice cream Otomatis, vol. 9, no. 2, pp. 129-137, 2019.

[4] P. Handoko, H. Hermawan, and S. Jaya, "Reverse Vending Machine Penukaran Limbah Botol Kemasan Plastik Dengan Tiket Sebagai Alat Tukar Mata Uang," Semin. Nas. Sains dan Teknol. 2018, pp. 1-12, 2018.

[5] R. A. Nugraha, A. Mulyani, and W. Gata, "Desain Vending Machine Rujak Buah Dengan Finite State Automata," IJCIT (Indonesian J. Comput. Inf. Technol., vol. 5, no. September, pp. 198-207, 2020.

[6] T. I. Saputra, F. Fauziah, and A. Gunaryati, "Simulasi Vending Machine Dengan Mengimplementasikan Finite State Automata," JOINTECS (Journal Inf. Technol. Comput. Sci., vol. 3, no. 3, pp. 143-148, 2018, doi: 10.31328/jointecs.v3i3.819.

[7] Handayani, D. Ismunandar, S. A. Putri, and W. Gata, "Penerapan Finite State Automata Pada Vending Machine Susu Kambing Etawa," Matics, vol. 12, no. 2, pp. 87-92, 2021, doi: 10.18860/mat.v12i2.9270.
[8] E. Erni, F. Titiani, S. A. Putri, and W. Gata, "Penerapan Konsep Finite State Automata Pada Aplikasi Simulasi Vending Machine Jamu Tradisional," J. Inform., vol. 7, no. 2, pp. 141-147, 2020, doi: 10.31294/ji.v7i2.8151.

[9] A. Faisal, G. V. Saragih, and W. Gata, "Desain Vending Machine Rokok Dengan Mengimplementasikan Finite State Automata Terintegrasi Dengan E-KTP," Matics, vol. 12, no. 1, p. 55, 2020, doi: 10.18860/mat.v12i1.8693.

[10] R. Kurniawati, I. Yuniar, and N. Wisna, "Desain Aplikasi Sistem Penjualan Obat dan Jasa Pelayanan Dokter BPJS," no. 3, pp. 96-101, 2018.

[11] A. Permatasari, "Rancangan Sistem... (Angelina Permatasari) RANCANGAN SISTEM INFORMASI PENJUALAN PADA TOKO KUE," no. 9, pp. 31-43.

[12] Bode, "Support Vector Machine Menggunakan Forward Selection untuk Prediksi Penjualan Obat penggunaanya yang disertai dengan dosis , waktu serta tanggal yang tepat," Tecnoscienza, vol. 3, pp. 1626, 2018.

[13] A. Brolin, R. Mithun, V. Gokulnath, and M. Harivishanth, "Design of automated medicine vending machine using mechatronics techniques," IOP Conf. Ser. Mater. Sci. Eng., vol. 402, no. 1, 2018, doi: 10.1088/1757899X/402/1/012044. 